\title{
The Zhongguo Trademark in Modern East Asia
}

\author{
Kirill Ole THOMPSON*
}

Thinking about the fall of the Tang (618-907) and the horrors of the Five Dynasties period (907-960), Confucian thinkers of the Song (960-1279) noted the socio-cultural resilience of Han peoples during the drawn out horrific Five Dynasties period ${ }^{1}$ and reflected on the significance of "Zhongguo" - in effect changing it from a purely geo-political term to an appellation infused with the Confucian Dao 道 (Way) of an intellectualcultural-ethical tradition. They effected this change by recasting the Dao as a Daotong 道統 (succession of the Way) that set conditions on the sort of politico-socio-familial conditions that would constitute a Zhongguo 中國 worthy of the name. ${ }^{2}$

In working out their new notion of the Confucian Daotong 道統, i.e., philosophy, practices, virtues, rites, arts, etc., Song Confucians were thinking of educated Han peoples who would cultivate the Confucian Dao - whether or not they still dwelt in the nostalgia laden "Central Plains" of Chinese civilization. ${ }^{3}$ At the same time, the resulting new Confucian Dao was general enough that other peoples could master and apply it even if they weren't Han peoples themselves. Hence, the Mongols could be Sinicized by mastering the

* Kirill Ole Thompson is an Associate Dean of Institute for Advanced Studies in Humanities and Social Sciences, National Taiwan University

1 James T.C. Liu comments, "[During the Five Dynasties, c]hronic disorder and invasions notwithstanding, [ethnic] Han China, by virtue of a large population, wide geographic area, and long tradition, held its own. In fact, vigorous economic growth sprang up in parts of the Yangtze River valley and farther south. As soon as peace returned, Han culture flourished once again with new and greater strength under the Sung (960-1276)" (Liu 1988, 1).

2 "Modern China" commences with the Song. As James T.C. Liu comments, "Sung China cannot be described as 'early modern,' for there was no later modern afterwards.... In the Chinese path of evolution, the Sung pattern was a most developed and advanced bureaucratic society" (Liu 1988, viii).

3 Interestingly, "Zhongguo" in pre-Qin texts did not name or refer uniquely to a single country or a whole empire; rather, it was a description that referred collectively to several states or principalities ("the central states") in the context of Eastern Zhou territory. Zhongguo vis-à-vis the outer world would come later. 
Daotong and "adopt[ing]Han ways" (Liu 1988, 2) during the Yuan (12711368), as could the Manchus in the Qing (1644-1912). In fact, Zhu Xi's account of the Confucian Daotong was canonized and made official by the Mongols during the Yuan and remained so until 1908 when the imperial examination system was terminated. By the same token, regionally, Japanese Tokugawa Confucians (1603-1868) immersed themselves in the Confucian canon, and sincerely asked whether Japan wasn't better qualified - by Confucian Daotong standards - to be called "Zhongguo" than was geographic Imperial China (Huang 2014). Moreover, Chosen Koreans (1392-1897), who had striven to master and even improve upon the classics associated with the new Confucian Daotong, asked whether any country, especially Korea, wasn't Zhongguo - in its own perspective (Huang 2014). ${ }^{4}$ Interestingly, Confucians in both Korea and Japan were utterly shocked when the celestial Chinese Ming Empire fell to the "barbarian" Manchus in 1644; that is, they wondered how grand old "Zhongguo" could so easily fall while at the same time they took considerable pride in their own Confucian cultivation, culture, and relative stability.

What was the genesis of this new Confucian Dao? Initially, during the Tang dynasty, Han Yu (768-824) and Li Ao (fl. 798) circulated the idea of an "orthodox succession" of early Confucianism. In this effort, they elevated the position of the Mencius, the Great Learning, the Mean, and the Book of Change, and demoted that of the Xunzi (fl. 298-238 B.C.E.), Yang Xiong (53 B.C.E.18 C.E.) and the Han Confucians in the Confucian pantheon. They presented the "orthodox succession" as running from the early sage kings through Confucius (551-479 B.C.E.) and Mencius (371-289 B.C.E.). As Qian Mu points out, Han $\mathrm{Yu}$ emulated the writing style of the pre-Qin Confucian masters, especially Mencius, and thus differed markedly from the Han Confucian predilection for plodding commentary and their realist "art of statecraft." Moreover, Han Yu promoted the ancient literary style, which stressed clarity and basic truth in sharp contrast to the baroque rococo of Tang literary traditions (Qian 1971, I: 9). Three of Han Yu's essays were particularly influential in breathing fresh life into Confucian values and culture: "Offerings to the Alligators," a critique of the negative impact of Buddhism on family relationships and Chinese society, "Inquiry into Human Nature," and "Inquiry into the Way" (Chan 1963, 450-456, Hartman 1986). ${ }^{5}$ Drawing on the Mean and creatively adapting early Confucian concepts, Li

4 This study was inspired by Chun-chieh Huang's broad, civilizational conception of "East Asian Confucianisms" and his notion of "Confucianism in East Asian perspective," stressing indigenous appreciations of Confucianianism.

5 Ironically, this idea of succession was inspired, at least in part, by the Chan Buddhist notion of succession. 
Ao argued for the deep ontological and practical roots of the Confucian human nature in "Restoring the Original Nature" (Chan 1963, 456-459).

By and large, Han Yu and Li Ao's Confucian movement languished in the Tang and Five Dynasties period; however, their ideas about human nature, the Way, ancient literary style, Dao succession, etc. were noticed and taken up in the early Northern Song by thinkers like Ouyang Xiu (1007-1072), Zeng Gong (1019-1083), and others. ${ }^{6}$ Ouyang Xiu also wrote a critique of Buddhism in the spirit of Han Yu titled, "Inquiry into Fundamentals" (Lunben 論本) (Qian 1971, I:19, Eagan 1984). Notably, Northern Song Confucians took a renewed interest in the pre-Qin masters- after which Mencius' standing in the Confucian pantheon rose markedly. Qian Mu remarks that these Northern Song scholars honored Confucius by elucidating the Confucian succession in order to "restore stability in the realm and dispel the pervasive lingering disorder" (Qian 1971, I:14). We needn't go into further detail about these scholars at present. Soon after this generation of innovative Confucian scholars, six seminal thinkers arose who contributed directly to the formation of the new Confucian Daotong and Neo-Confucianism: Zhou Dunyi (1017-1073), Shao Yong (1011-1077), Zhang Zai (1020-1077), Cheng Hao (1032-1085), Cheng Yi (1033-1107), and the Chengs' disciples. ${ }^{7}$ Fundamentally, these thinkers honored Confucius, Mencius, the Great Learning, and the Mean and grounded and connected their ideals and virtues under several binding concepts, such as the Dao 道 (the Way), tian 天 (heaven, nature), taiji 太極 (supreme polarity), li 理 (principle, pattern), $q i$ 氣(vital vapor), xing 性 (natural propensities), qing 情 (emotions), etc. Zhou Dunyi stressed cultivation and integrated all of the constituent concepts under the dynamic Supreme Polarity (taiji) and brought them into daily experience with yin, yang, and the five phases: earth wood, fire, water, metal (Adler 2014). ${ }^{8}$ A student of the Book of Change, Shao Yong stressed the ideals of governance and the probabilities of evolving phenomena (Birdwhistle 1989). Following Mencius, Zhang Zai was alert to the vital vapor giving rise to sensitivity, vitality, sentience, and order, the cultivation of which he deemed necessary to moral perspicacity and efficacy (Kasoff 1984). Cheng Hao had a deep personal insight into the single root of the original mind and the moral compass that it provides for human propensities, particu-

6 In Tokugawa Japan, scholars like Ito Jinsai and Ogyu Sorai preferred Han Yu's account of the Confucian succession as associated with the ancient literary style (Tucker 2002, 2006).

7 For extensive readings with commentaries, see (Chan 1963, 1965), pp.460-571.

8 Zhou Dunyi's ideas had immediate existential relevance because they apply simultaneously to the cosmos (macrocosm) and to human person (microcosm). Adler's account of Zhu Xi's adoption of Zhou Dunyi's ideas is compelling (2014). 
larly those of humaneness and appropriateness. And finally, Cheng Yi's new formulation that human nature is a manifestation of principle/pattern laid the solid groundwork for the Confucian naturalized theory of ethical relationship and sensitive interaction (Graham 1958, esp. 1986).

In the $12^{\text {th }}$ century, Zhu Xi (1130-1200) of the Southern Song redefined and remolded the new Dao succession by viewing the Confucian teachings of antiquity through the spectacles of the Northern Song masters, and picking out the best lines of insight and thought that they had channeled. Notably, Zhu Xi saw the early sage kings as nurturing and transmitting not only institutions and regulations but harmony- engendering rites and music. $\mathrm{He}$ saw them as acting on a keen sense of zhong 中 (utmost propriety) through which they were tolerant and always tried to strike a balance and create harmony among the nobles and their subject people. He saw them as manifesting humaneness and appropriateness and applying the Golden Rule through their choices and practices of the rites and music, and exercises of discretion. He saw Confucius as teaching and manifesting the way of humaneness and appropriateness in light of Heaven, the Golden Rule, and sensitivity to others in their own perspective (shu 恕). He saw Yan Hui as a devotee the Way and master of filial piety and ritual propriety. He saw Confucius' disciple Zisi as articulating the way of utmost propriety (zhong 中; the mean) as the path to achieving tranquility, equilibrium, balance, and harmony in the empire, and Zengzi as teaching the purpose and steps of Confucian education and cultivation in realizing and sustaining the great Way. ${ }^{9}$ Zhu Xi saw Mencius as bringing Confucius' virtues back to their roots in authentic human emotions, here and now. Indeed, he saw Mencius as recovering the sensitivity and compassion as well as the great spiritedness that lay at the heart of Confucius' Way. Finally, he fused and re-articulated the contributions of the various Northern Song masters from Zhou Dunyi to the Cheng brothers and their followers.

Zhu Xi articulated his notion of the new Dao succession several times, each time with subtle variations. ${ }^{10}$ In recent decades, scholars have pondered these articulations of the Confucian succession (Wilson 1995, Adler 2014), particularly in regard to Zhu's selection of which Northern Masters to uphold. According to my analysis, $\mathrm{Zhu} \mathrm{Xi}$ was attempting to construct the most well

9 Looking to accounts of zhong in the Mean, some traditional scholars liked to understand "Zhongguo" as signifying not "the Middle Kingdom," but rather the "Kingdom of Tranquility" or "Equilibrium" if not that of "Utmost Propriety." Stressing the martial ( $w u$ 武) over the cultural (wen 文), the PRC has turned decisively away from these "soft, civilized" conceptions and viewed itself as something like the "Central Super Power" in recent decades.

10 See Wing-tsit Chan's detailed discussion: “The New Tao-t’ung” (1989: 320-335). 
integrated and compelling system of ideas he could work out, and ultimately found that he was able to bind the leading ideas of these particular five Northern Song masters in a tight yet balanced and dynamic system of complementary ideas (Adler 2009, 2014, Thompson 2015).11 For present purposes, suffice it to say that Zhu Xi constructed a notion of new Dao succession which bore every appearance of applying to universal humanity and not just to Han or even just to regional peoples. The early sage kings, Confucius' and Mencius' schools, and the Northern Song masters, all lived in ethnic Han communities in geographic China. Nonetheless, their ideas bore lessons which people everywhere could learn and draw inspiration from, and in many instances did. Their "upright" Dao transmission of ideals, cultivations, arts, and associated institutions could be adopted (and adapted) to other peoples and cultures not only within geographic China but regionally; on a much broader, more intellectual level, they could be learned and adapted by intellectuals around the world. In either case, the people and intellectuals could imagine and possibly realize the living spirit of this refined China/ Zhongguo in their life, cultivation, and relationships as defined in the new Confucian Dao succession.

While the new Confucian Dao succession perhaps had a civilizing effect in geographic China and regionally, at the same time within China it can be said to have overly sanctified Han traditions and cast an ice-cold eye on the traditions and values of other peoples who were equally indigenous to geographic China. ${ }^{12}$ Moreover, representing agrarian continental traditions, this Dao was conservative, static, inward looking, and distrustful of difference, otherness, and change. This set of limitations came to fore in the early Ming (1368-1644) when outward looking leaders initiated overland and maritime contacts and interactions, epitomized in the expeditions of Zheng $\mathrm{He}$ (1371-1433) (Dryer 2007), and culminating in the exploits of Zheng Chenggong (1624-1662) and his lineage (Clements 2014). Unfortunately, the main lesson of Zheng He's voyages to conservative Confucian officialdom was that the outer world was inferior to the Middle Kingdom; hence, the court eunuchs and ministers henceforth kept external contacts, mercantilism, and trade to a minimum, and cast Zheng Chenggong as a mere sea pirate. Their

11 See the Appendix below.

12 Dieter Kuhn relates, "During the 319 years of Song rule, no 'China'... existed, but rather a territory divided among different... peoples... and states.... A Song history is a study in regionalism.... In the view of many Song intellectuals [however], the barbarians on their borders differed greatly from the Han.... [Importantly, because] they lacked the rituals of status differentiation... between prince and subject, father and son, man and woman.... They were despised as the cultural inferiors of the Han” (Kuhn 2008, 5). 
view continued to prevail even as the Western powers competed to pry open the gates of Chinese markets and trade in the $19^{\text {th }}$ century. ${ }^{13}$

China was ill-prepared to face the onslaught of the Western Powers in the $19^{\text {th }}$ century largely because the inward Chinese thinking in accord with the new Dao succession had, on one hand, cut China off from the technological developments going on in the rest of the world, and gridlocked China in enervating dynastic cycles, which reached a nadir precisely during the high tide of European imperialism in the $19^{\text {th }}$ century, on the other. ${ }^{14}$ At the same time, Tokugawa Japan - which had illustrious academic opponents as well as supporters of Zhu Xi's philosophy (Tucker 2002, 2006) - was very inward looking and fell to the more outward and forward looking Meiji regime soon after Admiral Perry landed at Kurihama in 1853. And, Chosen Korea, the Hermit Kingdom, remained defensive and inward looking for centuries, nested uneasily between China and Japan (Chung 1995, Deuchler 1992). ${ }^{15}$ Nonetheless, the learning and cultivation deployed in mastering the new Dao succession did pave the way for these lands in the Far East to begin to receive modern learning and to establish modern institutions and universities to modernize their infrastructures and economies, and thus improve the

13 On the maritime side of Chinese history, see (Dreyer 2007, Li 2010, Lo 2013, Tsai 1996, Zheng 2012). Maritime China developed somewhat independently of the agrarian-based, continental Chinese civilization. Despite that proponents of the new Confucian Dao succession tended to fiercely oppose China's maritime and frontier mercantilism and trade, nowadays the PRC is both 1) embracing the new Confucian Dao succession as laden with wisdom for harmonizing society and 2) celebrating the exploits of old maritime China as the PRC, for example, expands its navy and gets involved in the wider world. Regarding frontier mercantilism, China's interest in moving Han Chinese to the"autonomous" minority regions of Tibet and Xinjiang, springs more from the capitalistic imperative to exploit the natural resources and cheap minority labor of those regions than from ethno-nationalist ideology. China's crackdowns on those regions are more to protect capital investments and bolster ethnic Han support than in building inter-ethnic harmony and security. (American history similarly features the influx of "Americans" into the Dakota territories after the discovery of silver there and into the Cherokee territory of Oklahoma with free land and the possibility of oil. Nixon's FBI persecuted AIM (the American Indian Movement) to choke off Indian claims to oil, gas, and mineral rights on Indian lands (Matthiessen 1983). Still, this influx was not state-sponsored, as in China's case.)

14 Liu notes, "When the age of exploration in the West began the expansion of Europe, the course of world history was altered, but the Chinese continued evolving their own separate culture in their own separate way. The most characteristic features of Han Chinese life in the Sung remained recognizable in China until the twentieth century" (Liu 1988, 2).

15 Many Korean scholars dedicated themselves to elaborating, refining, and even perfecting Zhu Xi's new Confucian Dao succession; see Kalton's 1988 masterpiece. See also (Oh 2005). 
people's lives.

Above it was mentioned that, on an intellectual level, the transmission of ideals, cultivation, and institutions associated with Zhu's new account of the Confucian Dao succession could be studied, cultivated, and adopted by intellectuals around the world. In the early to mid- $19^{\text {th }}$ century, several prominent American Transcendentalists celebrated and embraced this body of Confucian teachings. Henry David Thoreau (1817-1862) not only published selections from the Four Books in the Transcendentalist literary journal The Dial but quoted from this text several times in Walden (1849) in "extolling the vital sphere between heaven and earth, the cultivation of virtue and integrity, and the possibility of daily self-renewal" (Thompson 1993, 2). Thoreau's mentor Ralph Waldo Emerson (1803-1882) stressed the sociability, ritual civility, and harmony engendering civic virtues of the Confucian Way. Thoreau and Emerson both envisioned a revival of the Celestial Empire (i.e. China/ Zhongguo) in New England as a place of, at once, Emerson's celebrated public civility and grace and Thoreau's sense of at oneness with nature and living in the present moment (Thompson 1993, Versluis, 1994). Over a century later, an intellectual-ethical movement called "Boston Confucianism" arose under the leadership of Tu Wei-ming, formerly of the HarvardYenching Institute, and Robert Neville and John Berthrong of Boston University. Tu Wei-ming espouses both Thoreau's sense of at oneness with nature and Emerson's sense of civility and grace while promoting their ideal of the committed public intellectual as society's conscience. ${ }^{16}$ In many publications, Neville and Berthrong elaborate on the Neo-Confucian metaphysics of creativity, natural and moral, as well as its notion of cultivation and ethics as a living philosophy. ${ }^{17}$ Finally, Roger Ames and David Hall have devised a unique Hawai'i Confucianism in harness with the American Pragmatism of William James and John Dewey to inculcate a vital, holistic conception of nature and society through which to view human life as contextual, interactive and based on role modeling in relational contexts (Ames 1987, 2001, 2011). Taking their cue from the Confucian Dao succession, they admire, study, and teach the relational connectivity and mutual responsibility of all people - across classes, cultures, and ethnicities - so as to promote the formation of a richly diverse yet harmonious and intimately interactive humanized world, one which equally respects the sanctity and diversity of the natural world - from which humanity draws not only suste-

$16 \mathrm{Tu}$ often cites the moral courage of Mencius as public intellectual and voice of conscience. See Tu $(1985,1993)$.

17 Regarding Neville, see Neville (2000) and Van Norden (2003); on Berthrong, see (Berthrong 1998, 2001, \& 2008). 
nance but ceaseless inspiration. ${ }^{18}$

The new Confucian Dao and notion of orthodox succession were harshly criticized in China for nearly a century, starting with the May $4^{\text {th }}$ Movement of 1919 at Peking University, which promoted Science and Democracy, and culminating with Chairman Mao's radical Marxist call to "Close Confucius' Shop" and the moral and cultural devastation wreaked during the Great Proletarian Cultural Revolution of 1966-1976. In the $21^{\text {st }}$ century, however, the rebirth of prosperity and free economic and social life without value underpinnings in China now leads people to feel an acute sense of meaninglessness, and existential crisis. As the Chinese have financial security and material comfort, they increasingly seek deep and sustainable life values and ethical guidance. Consequently, they display renewed interest in the Confucian Dao succession - throughout China and across all sectors of society, including officialdom and academia. High schools and universities all across China now offer "National Studies" programs, which stress Confucian thought and values. Moreover, expensive private Confucian academies teach traditional values, cultivations, as embodied in the Six Arts, and respectful conduct, to children of the affluent and well-heeled. Meanwhile, Taiwan where Confucian values have flourished uninterruptedly in family and society and scholars study the classics and practice the cultivations - is actively exporting the learning, values, and virtues of the Confucian Dao succession back to the leadership, society, and academia in the PRC, particularly Mencius' liberal notions of inborn sense of commiseration, heart that cannot bear to see the suffering of others, virtues of humaneness and appropriateness, inborn knowledge of the good, inborn capacity to carry out the good, and kingly Way, all of which will contribute to the development of a more compassionate and humane polity and society there. ${ }^{19}$

18 While seeking to master, express, and communicate this spirit of the "Celestial Empire," this spirit of "China/Zhongguo," Boston Confucianism and Hawai'i Confucianism alike espouse mainly cultural and socio-ethical concerns and have no explicit official or political aims or pretenses. In this sense, while they do aspire to have authentic beneficial intellectual, spiritual, and ethical import and impact, they aim more at what Chun-chieh Huang calls "Cultural China" than geographic or "political China," which itself stands in great need of the socio-political wisdom of the new Confucian Dao succession (Huang 2014).

19 For instance, every summer this IHS hosts a two-day Camp on East Asian Confucianisms for Young Scholars. Young scholars (i.e., Ph.D. students and candidates) from the PRC are always the most numerous and enthusiastic participants. This summer, participants also came from Japan and South Korea as well as from around Taiwan, stressing such themes as Mencius' benevolent, kingly way. 


\section{Bibliography}

Adler, Joseph A. 2014. Reconstructing the Confucian Dao: Zhu Xi's Appropriation of Zhou Dunyi. Albany: State University of New York Press. . 2009. “Zhu Xi’s Daotong.” (Google “Zhu Xi’s Daotong.” See Appendix below.)

Ames, Roger. 2011. Confucian Role Ethics, a Vocabulary. Hong Kong: Chinese University Press.

Ames, Roger, and David Hall. 1987. Thinking Through Confucius. Albany: SUNY Press. . 2001. Focusing the Familiar. Honolulu: University of Hawai'i Press.

Berthong, John. 1998. Transformations of the Confucian Way. Boulder: Westview Press. . 2008. Expanding Process. Albany: SUNY Press. , and Evelyn Nagai Berthrong. 2001. A Short Introduction to Confucianism. Oxford: Oneworld.

Birdwhistle, Anne D. 1989. Transition to Neo-Confucianism: Shao Yong on Knowledge and Symbols of Reality. Stanford: Stanford University Press.

Bol, Peter. 1994. "Cheng Yi and the Cultural Tradition.” In W. Peterson, A. Plaks, \& Y.Y. Shih ed. The Power of Culture: Studies in Chinese Cultural History. Hong Kong: University of Hong Kong Press.

Bruce, J. Percy. 1923. Chu Hsi and His Masters. London: Probsthain.

Chan, Wing-tsit, trans. and ed. 1963. A Source Book in Chinese Philosophy. Princeton: Princeton University Press. ed. \& trans. 1967. Zhu Xi and Lu Zuqian 1175 comp. Reflections on Things at Hand: The Neo-Confucian Anthology. New York: Columbia University Press.

. 1982. "Chu Hsi and Yuan Confucianism." In H. Chan and W. de Bary ed. Yuan Thought. New York: Columbia University Press.

. 1987. Chu Hsi: Life and Thought. Hong Kong: Chinese University Press. . 1989. Chu Hsi: New Studies. Honolulu: University of Hawai'i Press. . 1973. "Chu Hsi’s Completion of Neo-Confucianism.” Rpt. In 1987. Chu Hsi: Life and Thought.103-138.

, ed. 1986. Chu Hsi and Neo-Confucianism. Honolulu: University of Hawai'i Press.

Chang, Carsun. 1957. The Development of Neo-Confucian Thought. Vol. 1. New York: Bookman.

Chen, Chun. 1986. W. Chan tr. Neo-Confucian Terms Explained. New York: Columbia University Press.

Ching, Julia. 2000. The Religious Thought of Chu Hsi. Oxford: Oxford University Press.

Clements, Jonathan. 2004. Pirate King: Coxinga and the Fall of the Ming Dynasty. Phoenix Mill: Gloucestershire: Sutton Books. 
De Bary, Wm. and I. Bloom ed. 1999. Sources of Chinese Tradition. 2/e. New York: Columbia University Press.

Dreyer, Edward. 2007. China and the Oceans in the Early Ming Dynasty, 14051433. New York: New York: Pearson Longman.

Egan, Ronald C. 1984. The Literary Works of Ou-yang Hsiu (1017-72). Cambridgeshire and New York: Cambridge University Press.

Graham, A.C. 1958. Two Chinese Philosophers: Ch'eng Ming-tao and Ch'eng Yi-ch'uan. London: Lund Humphries. . 1986. "What was New in the Ch'eng-Chu Theory of Human Nature?" In Chan ed. Chu Hsi and Neo-Confucianism, pp.

Hartman, Charles. 1986. Han Yu and the Tang Search for Unity. Princeton: Princeton University Press.

Hsiao, K.C. 1979. F. Mote trans. A History of Chinese Political Thought. Vol.1. Princeton: Princeton University Press.

Huang, Chun-chieh. 2014. Ch.10, "The Idea of "Zhongguo" and Its Transformation in the Context of Early Modern Japan and Contemporary Taiwan.” In C.C. Huang ed. East Asian Confucianisms: Texts in Contexts. Goettingen and Taipei: V\&R unipress and National Taiwan University Press.

Jones, David, and J. He ed. 2015. Rethinking Zhu Xi: Emerging Patterns within the Supreme Polarity. Albany: SUNY Press.

Kalton, Michael. 1988. To Become a Sage: a Translation of Ten Diagrams on Sage Learning by Yi T'oegye (1501-1570). New York: Columbia University Press.

Kohn, Livia ed. 2001. Chen Tuan: Discussions and Translations. Cambridge: Three Pines Press.

Kuhn, Dieter. 2009. The Age of Confucian Rule: The Song Transformation of China. Cambridge, MA \& London: Belknap Press.

Lau, D.C. trans. 1970. Mencius. Harmondsworth: Penguin Books.

Li, Kangying. 2010. The Ming Maritme Trade Policy in Transition, 1366-1567. Weisbaden: Harrassowitz Verlag.

Liu, James T.C. 1988. China Turning Inward: Intellectual-Political Changes in the Early Twelfth Century. Cambridge, MA \& London: Council on East Asian Studies, Harvard University.

Liu, Kwang-ching ed. Orthodoxy in Late Imperial China. Berkeley: University of California Press.

Lo, Jung-pang. 2013. B. Elleman ed. China as a Sea Power, 1127-1368. Singapore: NUS Press.

Matthiessen, Peter. 1983. In the Spirit of Crazy Horse. New York: Viking Books.

Neville, Robert. 2000. Boston Confucianism. Albany: SUNY Press. , ed. 2001. W. Tu, Intro. Ultimate Realities. Albany: SUNY Press.

Oh, Jung-sun. 2005. A Korean Theology of Human Nature: with special attention to the works of Robert C. Neville and Tu Wei-ming. Lanham: University 
Press of America.

Qian, Mu. 1971. Zhuzi Xin-xue'an, 5 vols. (New Case Studies on Master Zhu's Learning). Taipei: Sanmin.

Spence, Jonathan, 1968. "Chang Po-hsing and the Kang Hsi Emperor.” Rpt. 1995

I Jn Jonathan Spence ed. Chinese Roundabout: Essays in History and Culture. New York: Norton Press.

Thompson, Kirill. 1993. "Thoreau's Appropriation of Chinese Philosophy in Walden." Paper presented at a Conference of the ROC Society for British and American Literature," hosted by the English Department, NCCU, Muzha, Taiwan, November 20, 1993.

. 2015. "Opposition and Complementarity in Zhu Xi's Thought." In D. Jones \& J. He ed. Rethinking Zhu Xi: Emerging Patterns within the Supreme Polarity. Albany: SUNY Press.

Tsai, Shih-shan Henry. 1996. The Eunuchs in the Ming Dynasty. Albany: SUNY Press.

Tu, Wei-ming. 1985. Confucian Thought: Selfhood as Creative Transformation. Albany: SUNY Press.

1993. Way, Learning, and Politics: essays on the Confucian Intellectual. Albany: SUNY Press.

Tucker, John. 2002. Ito Jinsai's Gomo Jigi and the Philosophical Definition of Early Japan. Leiden: Brill.

. 2006. Ogyu Sorai's Philosophical Masterpieces: The Bendo and Benmei. Honolulu: University of Hawai'i Press.

Van Ess, Hans. 2004. "The Completion of the Works of the Cheng Brothers and its Significance for the Learning of the Right Way of the Southern Song Period." T'oung Pao, 90 (2004), 264-298.

Van Norden, Bryan. 2003. "Review of Boston Confucianism." Philosophy East and West. 53:3: 413-417.

Versluis, Arthur. 1994. American Transcendentalism and Asian Religions. Oxford: Oxford University Press.

Wilson, Thomas. 1995. A Genealogy of the Way: The Construction and Uses of the Confucian Tradition in Late Imperial China. Stanford: Stanford University Press.

Zheng, Yangwen. 2012. China on the Sea: How the Maritime World Shaped Modern China. Leiden: Brill. 


\section{Appendix}

\section{“Zhu Xi's Daotong" by Joseph Adler}

\section{Notes on the Reconstruction of Zhou Dunyi's Library in Jiangzhou}

(Jiangzhou chongjian Lianxi xiansheng shutang ji 江州重建濂溪先生書堂記) ${ }^{1}$ Zhu Xi 朱喜 (1177) Translated by Joseph A. Adler (C) 2009

[This piece is Zhu Xi's fullest discussion of what he would later call the daotong 道統, or "succession of the Way" - the series of sages, beginning with the primordial sage Fuxi, who transmitted the Confucian dao 道 - and in particular the problematic gap between Mencius ( $4^{\text {th }} \mathrm{c}$. BCE) and the Northern Song period, when Zhou Dunyi 周敦匵 (1017-1073) recovered it. Since the Chan school of Buddhism claimed to have a direct, unbroken line of succession - from the Buddha through Bodhidharma and the Sixth Patriarch to the current lineage holders - Zhu was particularly concerned with the metaphysical status of the dao during the periods when it was not being taught and how it could be revived after such gaps, as this question underlay the claim that Song Confucians had real access to the dao. His explanation of those gaps is the same as his explanation of the problem of evil in individuals: the clouding effect of the mind's $q i$ 氣, which obscures the innate moral nature (xing 性).] The dao has never been lost from the world. It is only that its being entrusted to man [to carry out] has sometimes been interrupted and sometimes been continuous. Thus, in its practice in the world there have been periods of clarity and periods of obscurity. This is all the result of the Decree of Heaven (tianming 天命); it is not something that the power of human wisdom is capable of achieving. Of the variety of individual things produced and supported by the two [modes of] qi [i.e. yin 陰 and yang 陽] and the Five Phases (wuxing 五行), in their mixed and confused rising and falling and coming and going throughout Heaven above and earth below, not one lacks a definite pattern/order/principle ( $l i$ 理). The greatest of these are the human nature [consisting] of humanity, rightness, propriety and wisdom, ${ }^{2}$ and the

1 Hui'an xiansheng Zhu wengong wenji wenji 晦庵先生朱文公文集 (Zhu Xi’s Collected Papers) 78, in Zhu Jieren, Yan Zuozhi, Liu Yongxiang, eds., Zhuzi quanshu 朱子全 書 (Zhu Xi's Complete Works), 27 vols. (Shanghai: Shanghai guji chuban she, 2002), vol.24: 3739-3741. I have omitted two short sections in which Zhu Xi discusses the local officials responsible for the rebuilding of the library.

2 The "four constant virutes" in Mencius 2A.6 and 6A.6. 
human relations of master and servant, father and son, brothers, husband and wife, and friends. ${ }^{3} 2$

This being the case, the cyclical flow [of the dao] is completely full, leaving out nothing. ${ }^{4}$ So how can we think that the [alternation of] order and disorder from ancient times to the present is [evidence for] the existence and perishing [of the dao] $?^{5}$ In the circulation of $q i$ there are inequalities [in terms] of homogeneity and heterogeneity and discontinuity and unity, so in the human endowment there are differences [in terms] of purity and turbidity, dullness and clarity. Therefore, how the dao is entrusted to man and carried out in the world is only due to what Heaven confers and humans receive. ${ }^{6}$ It is certainly not due to the clever and presumptious individual's ability to speculate and conjecture. [For example] the River Chart (Hetu 河圖) came out [of the Yellow River] and the Eight Trigrams were drawn; the Luo Writing (Luoshu 洛書) appeared and the Nine Regions were arranged. ${ }^{7}$ Confucius, in reference to the flourishing and decline of "this culture" (siwen 斯文), ${ }^{8}$ never

3 The "five human relations," in Mencius 3A.4 and Zhongyong 20.

4 That is, the dao is the dynamic flow of cosmic order $(l i)$, which is immanent throughout the natural and social worlds.

5 Although social and political order can break down, it is nevertheless the case that things happen for reasons. Thus the presence of disorder in society does not mean that the natural and moral order $(l i)$ has ceased to exist.

6 This is the answer to the question of the dao's metaphysical status during periods when it is not being taught: it still resides in human nature, although that nature is obscured by the impure physical natures (qizhi zhi xing 氣質之性) with which people are endowed at birth. The variations in physical endowments are due to factors beyond human control - i.e. they are due to Heaven - such as the position of the five planets (see below).

7 The River Chart was a numerological diagram that appeared to the mythical sage Fuxi on the back of a dragon horse coming out of the Yellow River, and was used by him in his creation of the hexagrams and divination system of the Zhou Yi 周易 (or Yijing 易經, Scripture of Change). The Luo Writing was a similar drawing that appeared to the mythical Yu the Great (founder of the Xia dynasty) on the shell of a spirit-tortoise as he was controlling the flooding of the Yellow River, and figured into his laying out of the Nine Regions of ancient China. See Chu Hsi [Zhu Xi], Introduction to the Study of the Classic of Change (I-hsüeh ch' 'i-meng), trans. Joseph A. Adler (Provo: Global Scholarly Publications, 2002): 1-14. Zhu Xi's point here is that Fuxi and Yu were able to do what they did only because they happened to be exposed to the River Chart and Luo Writing. Similarly, the chance allotment of $q i$ in each person's physical endowment determines "how the dao is entrusted to man and carried out in the world." Factors such as these, occurring either by chance or for unknowable reasons - i.e. factors beyond human control - are typically attributed to Heaven.

8 See Analects 9:5: "If Heaven intended this culture to perish, it would not have given it to those of us who live after King Wen's death" (trans. Edward Slingerland, Confucius: Analects, with Selections from Traditional Commentaries [Indianapolis: Hackett, 2003]: 87). 3 
failed to attribute it to Heaven. It is clear that the Sage did not deceive us in regard to this.

As for Teacher [Zhou] Lianxi, if he did not receive the propagation of this dao conferred by Heaven, how did he continue it so easily after such a long interruption, and bring it to light so abruptly after such extreme darkness?

With the decline of the Zhou and the death of Mencius, the propagation of this dao was not continued; even less so from the Qin through the Han, Jin, Sui and Tang, until our Song. Then the Sage-ancestor [Taizu, founding father of the Song] received the Mandate. The Five Planets were in conjunction, marking a turning point in culture. Only then did the heterogeneous $q i$ homogenize and the divided $[q i]$ coalesce; a clear and bright endowment was received in its entirety by one man, and the Teacher [Zhou Dunyi] appeared. Without following a teacher (shifu 師傅), he silently registered the substance of the Way, constructed the Diagram and attached a text to it, ${ }^{9}$ to give an ultimate foundation to the essentials.

At that time, the Chengs ${ }^{10}$ were among those who saw and knew him, and they subsequently expanded and clarified his teaching. They caused the subtlety of Heavenly principle, the manifest human relations, the multitude of phenomenal things, and the mystery of ghosts and spirits all to be fully joined together into one [system]. Thus the tradition of the Duke of Zhou, Confucius, and Mencius was brilliantly illuminated again in that era. There were determined scholars who managed to study it and respectfully practice it, without losing its correctness. They were like those who appeared before the Three Dynasties. Ah! Such grandeur! Were it not for what Heaven conferred, how could we be part of this?

The Teacher was from the Zhou family. His taboo name was Dunyi, ${ }^{11}$ his style name was Maoshu; his family was from Chongling. ${ }^{12} \mathrm{He}$ retired to the foot of Lushan, naming the river there after one from his old village, Lianxi (Lian Stream), took that as his honorific name, and built his library on its bank. His grave is now ten $l i$ south, in Jiuzhiang district, and has been 4 overgrown for years. ... I have been fortunate to have heard the teachings of the Chengs, and consequently read the Teachers writings and saw how he was

9 The "Explanation of the Supreme Polarity Diagram." See Wm. Theodore de Bary and Irene Bloom, eds., Sources of Chinese Tradition, $2^{\text {nd }}$ ed. (New York: Columbia University Press, 1999), vol.1: 672-676.

10 Cheng Hao 程影 (1032-1085) and Cheng Yi 程頣 (1033-1107).

11 He changed his given name, Dunshi 敦實, to Dunyi in 1063 to avoid the personal name of the new emperor, Zhao Zongshi 趙宗實 (Emperor Yingzong), even though Zhao Zongshi had changed his name to Zhao Shu 曙in 1062.

12 In modern Hubei province. 
as a man. ... I have inquired into how the Teacher received the Way from heaven and transmitted it to others, in order to likewise transmit the events of his life, to enable later gentlemen to contemplate, examine, and promote it. ... 